\title{
ARAHAN REKOMENDASI POLA RUANG IDEAL UNTUK PEMBANGUNAN DAN PENGEMBANGAN PERUMAHAN DAN KAWASAN PERMUKIMAN DI KABUPATEN POSO, PROVINSI SULAWESI TENGAH
}

\section{Oleh}

Tri Budiharto

Email: tri.budiharto@universitasbosowa.ac.id

Dosen Prodi Teknik PWK, Fakuktas Teknik, Universitas Bosowa

\begin{abstract}
ABSTRAK
Penelitian ini dilakukan di Kabupaten Poso dengan menggunakan metode penelitian gabungan kualitatif dan kuantitatif. Alternatif lahan yang dapat digunakan untuk perumahan dan kawasan permukiman diperoleh dengan melakukan serangkaian analisis dimulai dari tahapan analisis proyeksi pertumbuhan penduduk time series, tahap analisis kemampuan lahan, tahap analisis nilai potensi pertumbuhan permukiman dan tahap analisis perkembangan permukiman.

Lahan yang digunakan untuk perumahan dan kawasan permukiman harus memenuhi persyaratan yang layak huni untuk dapat berlanjut (sustainable). Lahan yang dapat digunakan adalah lahan non produktif, lahan yang kemiringannya di bawah 25\%, memiliki kecenderungan kompak, sesuai dengan rencana tata ruang wilayah Kabupaten Poso, tidak rawan bencana (tsunami, gempa bumi, banjir, longsor dan abrasi), serta bukan daerah negative list.

Berdasarkan hasil penelitian, luasan Pola Ruang untuk perumahan dan kawasan permukiman dalam Revisi RTRW Kabupaten Poso belum mempertimbangkan Kawasan negative list antara lain KP2B, Kawasan pengukuhan kehutanan sesuai SK 8113, Kawasan pertambangan dengan status IUP Produksi, Kajian Kawasan Rawan Bencana. Arahan Pola Ruang ideal yang direkomendasikan untuk pembangunan dan pengembangan perumahan dan kawasan permukiman adalah sebesar 6.666,64 Ha. Besaran alokasi ruang ini lebih besar 508,12 Ha dari alokasi ruang dalam revisi RTRW Kabupaten Poso.
\end{abstract}

Kata Kunci: Arahan Pola Ruang Ideal, Pembangunan dan Pengembangan, Perumahan Dan Kawasan Permukiman 


\begin{abstract}
This research was conducted in Poso Regency using a combination of qualitative and quantitative research methods. Alternative land that can be used for housing and residential areas is obtained by conducting a series of analyzes starting from the time series population growth projection analysis stage, the land capability analysis stage, the settlement growth potential value analysis stage and the settlement development analysis stage.

Land used for housing and settlement areas must meet the requirements that are suitable for habitation in order to be sustainable. Land that can be used is non-productive land, land with a slope of less than 25\%, has a tendency to be compact, in accordance with the spatial plan for the Poso Regency area, is not prone to disasters (tsunamis, earthquakes, floods, landslides and abrasion), and is not a negative area. list.

Based on the results of the research, the area of the Spatial Pattern for housing and residential areas in the Revised RTRW of Poso Regency has not considered the negative list areas, including KP2B, Forestry Confirmation Areas in accordance with SK 8113, Mining areas with Production IUP status, Disaster Prone Area Studies. The ideal spatial pattern direction recommended for the construction and development of housing and settlement areas is 6,666.64 Ha. The amount of this space allocation is greater than $508.12 \mathrm{Ha}$ from the space allocation in the revised RTRW for Poso Regency.
\end{abstract}

Keywords: Direction of Ideal Spatial Patterns, Development and Development, Housing and Settlement Areas

\section{A. PENDAHULUAN}

Berdasarkan (PP No. 12 Tahun 2021 tentang Perubahan atas Peraturan Pemerintah Nomor 14 Tahun 2016 tentang Penyelenggaraan Perumahan dan Kawasan Permukiman, 2021) Perumahan adalah kumpulan rumah sebagai bagian dari permukiman, baik perkotaan maupun pedesaan, yang dilengkapi dengan prasarana, sarana, dan utilitas umum sebagai hasil upaya pemenuhan rumah layak huni. Permukiman adalah bagian dari lingkungan hunian yang terdiri atas lebih dari satu satuan perumahan yang mempunyai prasarana, sarana, utilitas umum, serta mempunyai penunjang kegiatan fungsi lain di kawasan perkotaan atau kawasan perdesaan. Perumahan dan kawasan permukiman adalah satu kesatuan sistem 
yang terdiri atas pembinaan, penyelenggaraan, perumahan, penyelenggaraan kawasan permukiman, pemeliharaan dan perbaikan, pencegahan dan peningkatan kualitas terhadap perumahan kumuh dan permukiman kumuh, penyedian tanah, pendanaan dan sistem pembiayaan, serta peran serta masyarakat. Perumahan dan kawasan permukiman merupakan salah satu kebutuhan dasar bagi kehidupan manusia yang berfungsi sebagai tempat tinggal untuk berlindung dan bersosialisasi. Kebutuhan akan perumahan dan kawasan permukiman dari tahun ke tahun terus mengalami peningkatan, seiring dengan meningkatnya jumlah penduduk suatu wilayah. Rumah tidak hanya dipandang sebagai kebutuhan untuk tempat tinggal saja, tapi lebih bagaimana menciptakan suasana yang layak huni (livible), aman (safe), nyaman (comfortable), damai (peaceful) dan sejahtera (prosperous) serta berkelanjutan (sustainable) (Kusuma, 2017).

Lahan yang merupakan faktor utama sebagai dasar dalam pembangunan perumahan dan kawasan permukiman seringkali menjadi masalah karena keterbatasan luasan yang tersedia terutama di kawasan pusat kota. Terlebih lagi wilayah kabupaten Poso memiliki kerawanan bencana yang cukup tinggi yang terdiri dari tsunami, gempa bumi, banjir, longsor dan abrasi sehingga kesalahan dalam penempatan arahan penggunaan lahan untuk perumahan dan kawasan permukiman dapat berakibat fatal bagi keselamatan masyarakat.

Dari penjelasan diatas, maka akan menarik untuk dilakukan suatu penelitian mengenai arahan rekomendasi pola ruang ideal untuk pembangunan dan pengembangan perumahan dan kawasan permukiman sehingga dapat menjadi masukan bagi stakeholders dalam mengatasi permasalahan kelangkaan lahan serta dapat memberikan masukan dan motivasi bagi untuk dapat mencari alternatif lokasi pembangunan dan pengembangan perumahan dan kawasan permukiman yang sesuai di Kabupaten Poso dengan tidak meninggalkan aspek-aspek dasar dalam pemilihan lokasi perumahan serta kelestarian lingkungan hidup.

\section{B. RUMUSAN MASALAH}

Rumusan masalah dalam penelitian ini antara lain sebagai berikut:

1. Bagaimana kesesuaian arahan penggunaan Ruang untuk Perumahan dan Kawasan Permukiman di Kabupaten Poso?

2. Bagaimana Alternatif lahan yang dapat digunakan untuk pembangunan dan 
pengembangan perumahan dan kawasan permukiman di Kabupaten Poso?

\section{METODE PENELITIAN}

Penelitian ini dilakukan di Kabupaten Poso dengan menggunakan metode penelitian gabungan kualitatif dan kuantitatif. Alternatif lahan yang dapat digunakan untuk perumahan dan kawasan permukiman diperoleh dengan melakukan serangkaian analisis dimulai dari tahapan analisis proyeksi pertumbuhan penduduk time series, tahap analisis kemampuan lahan, tahap analisis nilai potensi pertumbuhan permukiman dan Tahap analisis perkembangan permukiman. Berdasarkan hasil analisis beberapa data sesuai dengan persyaratan seperti tersebut diatas, sehingga lahan yang dapat digunakan adalah lahan non produktif, lahan yang kemiringannya di bawah 25\%, memiliki kecenderungan kompak, sesuai dengan rencana tata ruang wilayah Kabupaten Poso, tidak rawan bencana (tsunami, gempa bumi, banjir, longsor dan abrasi), bukan daerah negative list.

\section{HASIL PENELITIAN DAN \\ PEMBAHASAN}

\section{Sejarah, Pola dan kecenderungan perkembangan perumahan dan Kawasan permukiman Kabupaten Poso}

\author{
Berdasarkan informasi dari \\ ('Wikipedia Poso (kota)', 2021) \\ Perkembangan perumahan dan Kawasan \\ permukiman di Kabupaten Poso berasal dari \\ perkembangan kota pelabuhan kecil di muara
} Sungai Poso pada akhir abad ke-19 dan perkembangan pusat hunian baru di Tentena oleh Pemerintah Hindia Belanda. Perkembangan kota pelabuhan kecil di muara Sungai Poso merupakan aglomerasi dari tiga kecamatan, yaitu Poso Kota, Poso Kota Utara dan Poso Kota Selatan. Kawasan Perkotaan Poso merupakan perkotaan tertua di Sulawesi Tengah, dan merupakan salah satu kota penting bagi Belanda untuk mengontrol wilayah selatan Teluk Tomini pada awal kedatangannya. Kawasan Perkotaan Tentena merupakan aglomerasi dari dua kecamatan yaitu Pamona Puselemba dan Pamona Utara. Kawasan ini terletak di pinggiran Danau Poso, sekitar $54 \mathrm{~km}$ sebelah tenggara dari Kota Poso. Pada akhir abad ke-19, Tentena adalah pusat pelayanan publik. Dua jenis pelayanan publik pada saat itu adalah pendidikan dan kesehatan. Dalam memenuhi kepentingan masyarakat, Zending banyak 
mendirikan kantor-kantor pelayanan di Tentena seperti Limbue yaitu kantor sinode pertama sebelum didirikannya kantor sinode GKST di Jalan Setia Budi, Kelurahan Sangele. Pada tahun 1902, Kruyt mengajak masyarakat yang bermukim di pegunungan untuk turun, dan kemudian menempati pemukiman baru yang telah disediakan. Pada tahun 1905, zending secara efektif menjalankan pembangunannya di Tentena. Pada tahun 1940, Raja Talasa tua mengutus putra sulungnya, Wongko Talasa, sebagai raja muda untuk mengepalai pemerintahan di Tentena. Pada tahun 1950, pemerintah Hindia Belanda mendatangkan beberapa mesin gergaji dan para instruktur untuk melatih masyarakat di wilayah Tentena sebagai tempat hunian baru. Salah satu tempat untuk menghasilkan bahan baku rumah penduduk, berada di wilayah Tandongkayuku.

\section{Kecenderungan Perkembangan Fisik}

Perkembangan pusat kota suatu wilayah tidak lain akibat adanya pertumbuhan modal dan pertumbuhan sumber daya di wilayah tersebut. Semakin intensifnya perkembangan keduanya mendorong pertumbuhan sektor-sektor pendukung lainnya. Di pusat kota terdapat kemudahan-kemudahan untuk memenuhi kebutuhan manusia hal ini semakin kuat daya tariknya mengundang manusia (migrasi) dan kegiatan ekonomi untuk datang ke tempat tersebut. Akibat munculnya aktivitas tersebut mendorong para pendatang tersebut membangun areal permukiman. Namun dengan semakin luasnya perkembangan sektor perdagangan dan jasa di pusat kota tersebut dan seiring dengan semakin mahalnya harga lahan maka terjadi perubahan kecenderungan pemanfaatan lahan kota.

Kecenderungan perkembangan fisik di Kabupaten Poso, pada hakekatnya tercermin dari bentuk struktur keruangan wilayah yang terbentuk karena posisinya secara geografis dan karakteristik tempatnya. Kabupaten Poso secara umum dan garis besar, pola kecenderungan pekembangan fisik perumahan dan kawasan permukimannya mengikuti kondisi prasarana khususnya kondisi jalur jalan. Arah kecenderungan perkembangan secara fisik Kabupaten Poso berorientasi pada pesisir Laut Teluk Tomini dan Danau Poso. Perkembangan secara fisik yang berasal dari pesisir Laut Teluk Tomini berkembang dari arah muara Sungai Poso yang merupakan aglomerasi permukiman dari tiga kecamatan, yaitu Poso Kota, Poso Kota Utara dan Poso Kota Selatan memanjang ke arah Barat 
(Kecamatan Poso Pesisir dan Kecamatan Poso Pesisir Utara) dan membentang berkembang ke bagian selatan (Kecamatan Lage). Perkembangan secara fisik yang berasal dari pesisir Danau Poso merupakan perkembangan aglomerasi dari dua kecamatan yaitu Pamona Puselemba dan Pamona Utara. Pola kecenderungan pekembangan fisik perumahan dan kawasan permukimannya mengikuti kondisi prasarana khususnya kondisi jalur jalan. Perkembangan ini cenderung sebagai wilayah terbangun (built up area) Kawasan Perkotaan Poso dan Kawasan Perkotaan Tentena.

Pengertian aglomerasi adalah kencederungan persebaran yang bersifat mengelompok pada suatu wilayah yang relatif sempit dan paling menguntungkan, terutama berkaitan dengan aktifitas manusia. Di Kabupaten Poso, indikator aglomerasi dapat dilihat antara lain seperti persebaran permukiman perkotaan dan perdesaan yang terintegrasi dengan lahan usaha pertanian.

Pola dan sebaran aglomerasi permukiman dan lahan pertanian penduduk di Kabupaten Poso sangat dipengaruhi oleh kondisi fisik dasar lahan. Pusat-pusat permukiman dan kegiatan pertanian tersebar mengelompok setempat-setempat pada lahan datar dan agak landai di sepanjang pantai, daerah aliran sungai dan bantaran danau.
Berdasarkan hasil tumpang susung peta lereng dan penggunaan lahan untuk permukiman, maka pengelompokan permukiman yang terjadi di Kabupaten Poso dapat di identifikasi sebagai berikut:

- Pengelompokkan permukiman di Kecamatan Poso Pesisir Utara memanjang mengikuti lahan datar dan agak landai di sepanjang pesisir bagian utara.

- Pengelompokkan permukiman di Kecamatan Poso Pesisir dan Poso Pesisir Selatan, sebagian besar terkonsentrasi pada lahan datar di bantaran daerah aliran sungai Puna

- Pengelompokkan permukiman perkotaan Poso di Kecamatan Poso Kota, Poso Kota Utara, Poso Kota Selatan dan Lage, terutama terkonsentrasi pada lahan datar di muara sungai Poso serta bantaran daerah aliran sungai Poso

- Pengelompokkan permukiman di Kecamatan Pamona Utara dan Pamona Puselemba, terutama terkonsentrasi pada lahan datar bantaran Danau Poso bagian utara pada hulu sungai Poso.

- Pengelompokkan permukiman di kecamatan Pamona Barat, terkonsentrasi pada lahan datar bantaran Danau Poso bagian barat.

- Pengelompokkan permukiman di Kecamatan Pamona Selatan dan Pamona 
Tenggara, terkonsentrasi pada lahan datar daerah aliran sungai Kodina dan bataran danau Poso di bagian selatan dan timur danau

- Pengelompokkan permukiman di Kecamatan Pamona Timur, menyebar setempat setempat pada dataran daerah aliran sungai Walati dan Yaentu.
Lore Peore, menyebar pada daerah datar dataran tinggi Napu.

- Pengelompokkan permukiman di Kecamatan Lore Tengah, terkonsentrasi di dataran tinggi Besoa.

- Pengelompokkan permukiman di Kecamatan Lore Selatan dan Lore Barat, terkonsentrasi di dataran lembah Bada.

- Pengelompokkan permukiman di Kecamatan Lore Utara, Lore Timur, dan

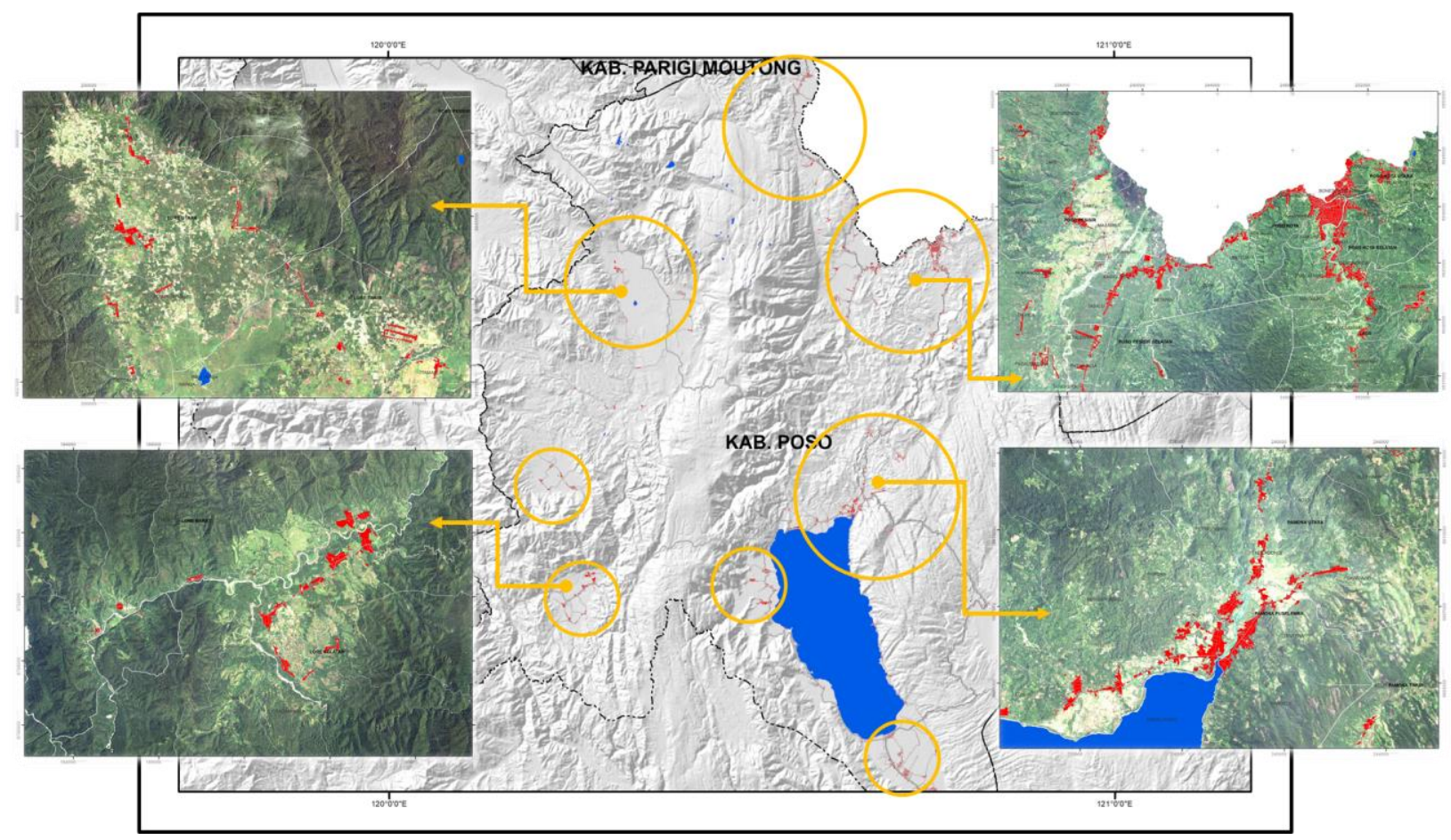

Gambar 1. Pemusatan dan aglomerasi Permukiman di Kabupaten Poso

Dalam proses pertumbuhan perumahan dan Kawasan permukimannya, terdapat kutub pengembangan yang secara desentralisasi akan memberikan dorongan pertumbuhan pada pusat-pusat pengembangannya. Kecenderungan perkembangan perumahan dan kawasan permukiman diwilayah studi, perlu dicermati dan segera ditangani sebelum berkembang menjadi permasalahan yang lebih kompleks dan sulit terkendali/ ditangani. Kecenderungan perkembangan di kawasan 
studi menunjukan beberapa hal yang perlu dicermati (karena dampak negatif yang ditimbulkan oleh perembetan tidak kompak/ meloncat) yaitu:

- Perembetan meloncat merupakan salah satu bentuk perembetan kota yang tidak efektif dan efisien, baik dari segi ekonomi, fisik, sosial dan sebaginya.

- Permasalahan perubahan fungsi lahan lindung menjadi kawasan permukiman

- Pertumbuhan dan perembetan kota terjadi secara sporadis, berpencar, memakan lahan lindung yang menjadi kawasan permukiman terjadi di beberapa kawasan di Kabupaten Poso. Kawasan permukiman tersebut menempati lahan lindung/konservasi yang subur dan sangat potensial, baik berupa kawasan yang memberikan perlindungan kawasan bawahannya; kawasan perlindungan setempat; kawasan suaka alam dan cagar budaya serta kawasan rawan bencana alam.

- Permasalahan Penyediaan sarana prasarana

- Pola perembetan meloncat selain membawa dampak negatif berbagai permasalahan diatas, juga memberikan dampak negatif pada pembangunan dan penyediaan prasarana dan sarana perumahan dan kawasan permukiman bagi pemerintah daerah setempat. Terutama dalam hal ini adalah mahalnya biaya perpanjangan jaringan pelayanan prasarana dari pusat pelayanan.

\section{Kecenderungan Perkembangan Non Fisik}

Kecenderungan perkembangan secara non fisik dapat dilihat melalui pola pemilikan dan nilai tanah. Harga lahan dan pajak lahan juga merupakan salah satu variable yang mempengaruhi penentuan lokasi (Dewi and Sunaryo, 2013, p. 436). Batas-batas area tanah, status pemilikan tanah dan nilai tanah seringkali menjadi problem pembangunan baik yang dilaksanakan oleh pemerintah, swasta maupun masyarakat. Status tanah dibedakan menurut penguasaannya terdiri dari tanah negara, hak milik, hak guna usaha dan hak guna bangunan. Tanah milik dapat berbentuk hak milik (sertifikat), hak milik yayasan, dan hak milik adat.

Dalam pemberian sertifikat tanah harus diperhatikan peruntukan lahan yang ada di kawasan tersebut. Jangan sampai pemberian sertifikat berada di lahan yang bukan peruntukan sebagai permukiman seperti hutan lindung dan kawasan konservasi.

Sementara itu nilai tanah juga memegang peranan dalam beberapa aspek kegiatan pembangunan. Selain tata letak dan 
potensi tanah yang menjadi tolak ukur harga/nilai tanah, faktor rencana peruntukan lahan sering merangsang naiknya nilai tanah yang bersangkutan. Tanah yang berada di pusat kota serta yang mempunyai letak Kestrategisan terhadap suatu lokasi jelas akan berpengaruh terhadap nilai lahan, yaitu nilai lahan akan semakin mahal seiring dengan semakin dekatnya letak lahan tersebut dengan pusat kota (CBD), begitupun sebaliknya.

\section{Kepadatan Bangunan Perumahan dan}

\section{Kawasan Permukiman}

Standar untuk menentukan tingkat kepadatan bangunan dapat dikategorikan dengan perbandingan antara luas permukiman dengan jumlah rumah. Kategorinya adalah $<30$ unit/Ha kategori rendah, 30-40 unit/Ha kategori sedang, dan $>40$ unit/Ha kategori tinggi. Intensitas kepadatan bangunan kawasan perumahan dan kawasan permukiman di Kabupaten Poso pada tahun 2017 dikatakan rendah. Kepadatan bangunan terjadi terjadi akibat kecenderungan pengelompokan pembangunan perumahan disuatu wilayah, di kecamatan-kecamatan tertentu yang memiliki kondisi representatif sebagai kawasan perumahan dan kawasan permukiman. Pada tahun 2039 dikecamatan Poso Kota Utara dan Kecamatan Lore Peore tanpa ekstensifikasi luasan lahan untuk Kawasan permukiman diprediksi dapat terjadi kepadatan bangunan yang tinggi karena lahan yang diperuntukan untuk permukiman di wilayah tersebut sangat terbatas. Tabel berikut merupakan intensitas kepadatan bangunan kawasan perumahan dan kawasan permukiman di Kabupaten Poso.

Tabel 1. Analisis Kepadatan Bangunan di Kabupaten Poso Tahun 2017-2039

\begin{tabular}{|c|c|c|c|c|c|c|c|}
\hline Kecamatan & $\begin{array}{c}\text { Jumlah } \\
\text { Rumah } \\
\text { Tahun } \\
2017 \\
\text { (Unit) }\end{array}$ & $\begin{array}{c}\text { Luas } \\
\text { Kawasan } \\
\text { Permukiman } \\
\text { (Ha) }\end{array}$ & $\begin{array}{c}\text { Kepadatan } \\
\text { Bangunan } \\
\text { (Unit/Ha) }\end{array}$ & Klasifikasi & $\begin{array}{c}\text { Proyeksi } \\
\text { Jumlah } \\
\text { Rumah } \\
\text { Tahun } 2039 \\
\text { (Unit) }\end{array}$ & $\begin{array}{c}\text { Kepadatan } \\
\text { Bangunan } \\
\text { (Unit/Ha) }\end{array}$ & Klasifikasi \\
\hline Poso Kota & 4120 & 298,42 & 13,81 & Rendah & 7540 & 25,27 & Rendah \\
\hline Poso Kota Utara & 2554 & 179,95 & 14,19 & Rendah & 5143 & 28,58 & Rendah \\
\hline Poso Kota Selatan & 2431 & 199,26 & 12,20 & Rendah & 4182 & 20,99 & Rendah \\
\hline Poso Pesisir & 5180 & 410,73 & 12,61 & Rendah & 9353 & 22,77 & Rendah \\
\hline Poso Pesisir Selatan & 2339 & 183,72 & 12,73 & Rendah & 4111 & 22,38 & Rendah \\
\hline Poso Pesisir Utara & 3931 & 335,40 & 11,72 & Rendah & 7296 & 21,75 & Rendah \\
\hline
\end{tabular}




\begin{tabular}{|c|c|c|c|c|c|c|c|}
\hline Kecamatan & $\begin{array}{c}\text { Jumlah } \\
\text { Rumah } \\
\text { Tahun } \\
2017 \\
\text { (Unit) }\end{array}$ & $\begin{array}{c}\text { Luas } \\
\text { Kawasan } \\
\text { Permukiman } \\
\text { (Ha) }\end{array}$ & $\begin{array}{c}\text { Kepadatan } \\
\text { Bangunan } \\
\text { (Unit/Ha) }\end{array}$ & Klasifikasi & $\begin{array}{c}\text { Proyeksi } \\
\text { Jumlah } \\
\text { Rumah } \\
\text { Tahun } 2039 \\
\text { (Unit) }\end{array}$ & $\begin{array}{c}\text { Kepadatan } \\
\text { Bangunan } \\
\text { (Unit/Ha) }\end{array}$ & Klasifikasi \\
\hline Lage & 4669 & 296,68 & 15,74 & Rendah & 8456 & 28,50 & Rendah \\
\hline Pamona Utara & 2772 & 261,34 & 10,61 & Rendah & 5680 & 21,73 & Rendah \\
\hline Pamona Puselemba & 4513 & 411,83 & 10,96 & Rendah & 8363 & 20,31 & Rendah \\
\hline Pamona Barat & 2126 & 245,40 & 8,66 & Rendah & 4340 & 17,69 & Rendah \\
\hline Pamona Tenggara & 1537 & 92,53 & 16,61 & Rendah & 3011 & 32,54 & Sedang \\
\hline Pamona Timur & 2430 & 144,63 & 16,80 & Rendah & 4429 & 30,62 & Sedang \\
\hline Pamona Selatan & 4544 & 460,02 & 9,88 & Rendah & 8547 & 18,58 & Rendah \\
\hline Lore Barat & 732 & 76,13 & 9,61 & Rendah & 1305 & 17,14 & Rendah \\
\hline Lore Selatan & 1156 & 204,86 & 5,64 & Rendah & 2613 & 12,76 & Rendah \\
\hline Lore Peore & 822 & 30,38 & 27,06 & Rendah & 1365 & 44,92 & Tinggi \\
\hline Lore Tengah & 1021 & 108,12 & 9,44 & Rendah & 1871 & 17,30 & Rendah \\
\hline Lore Timur & 1345 & 77,95 & 17,26 & Rendah & 2264 & 29,04 & Rendah \\
\hline Lore Utara & 2510 & 141,70 & 17,71 & Rendah & 4427 & 31,24 & Sedang \\
\hline Kabupaen Poso & 50732 & 4159 & 12,20 & Rendah & 94295 & 22,67 & Rendah \\
\hline
\end{tabular}

Sumber: Hasil Analisis BPS Kabupaten Poso Tahun 2018, Data Keluarga Dinas PKP dan BKKBN diakses Tahun 2019

\section{Analisis Kebutuhan Pembangunan Baru Perumahan Dan Kawasan Permukiman}

Cara menghitung proyeksi kebutuhan rumah dapat dilakukan dengan beberapa metode. Hal ini tergantung dengan ketersediaan data, kondisi wilayah setempat dan kecenderungan perkembangannya. Idealnya setiap penduduk harusnya menempati rumah seluas $7,2 \mathrm{~m}^{2} /$ penduduk (standar Kemen Pekerjaan Umum dan Perumahan Rakyat), 8 m²/penduduk (standar Dinas Kesehatan) atau $10 \mathrm{~m}^{2} /$ penduduk (standart WHO). Jadi proyeksi kebutuhan rumah yang ideal dapat dilakukan dengan membandingkan antara jumlah penduduk setiap tahun proyeksi terhadap kebutuhan luas rumah.

Kepadatan bangunan yang tinggi mendorong meningkatnya pembangunan baru perumahan dan kawasan permukiman. Kebutuhan rumah untuk masyarakat di Kabupaten Poso belum semuanya terpenuhi. Hal ini dapat dilihat dari jumlah kekurangan rumah yang masih banyak. Berdasarkan jumlah rumah tahun 2017 Kecamatan yang memiliki jumlah rumah terbanyak adalah di 
Kecamatan Posos Pesisir sebesar 5.180 unit dan memiliki kekurangan jumlah rumah sebesar 838 unit.

Dasar perhitungan luasan kapling yang digunakan untuk perhitungan adalah: Menggunakan kebijakan berimbang yang diatur dalam (PP No. 12 Tahun 2021 tentang Perubahan atas Peraturan Pemerintah Nomor $14 \quad$ Tahun 2016 tentang Penyelenggaraan Perumahan dan Kawasan Permukiman, 2021) yaitu pola hunian berimbang 1:2:3 (1 rumah mewah lebih dari $200 \mathrm{~m}^{2}, 2$ rumah sedang/menengah antara $150 \mathrm{~m}^{2}, 3$ rumah sederhana/kecil antara 72 $\mathrm{m}^{2}$ ). Pola hunian berimbang 1:2:3 adalah dalam satu kawasan terdapat satu rumah mewah, dua rumah menengah, dan tiga rumah sederhana. Dalam hal Pelaku pembangunan perumahan tidak dapat membangun rumah sederhana, Pelaku pembangunan perumahan dapat membangun Rumah Susun Umum yang jumlahnya senilai dengan harga kewajiban membangun Rumah Sederhana. Berdasarkan (UU No. 1 Tahun 2011 tentang Perumahan dan Kawasan Permukiman, 2011) yang mewajibkan badan hukum yang melakukan pembangunan perumahan untuk mewujudkan perumahan dengan hunian berimbang. Peraturan tersebut ditujukan bagi pengembang untuk membangun rumah sejahtera tapak bagi kebutuhan masyarakat kecil.

Penerapan pola hunian berimbang juga dipengaruhi oleh harga lahan. Berdasarkan harga lahan di Kabupaten Poso untuk rumah tipe kecil kisaran harganya adalah 50-100 juta, tipe rumah sedang seharga 150-250 juta, sedangkan tipe rumah mewah berkisar lebih dari 250 juta. Setiap tahunnya harga rumah memiliki kenaikan sebesar 20\% karena dipengaruhi oleh harga lahannya sendiri dan bahan bangunan yang juga terus meningkat. 


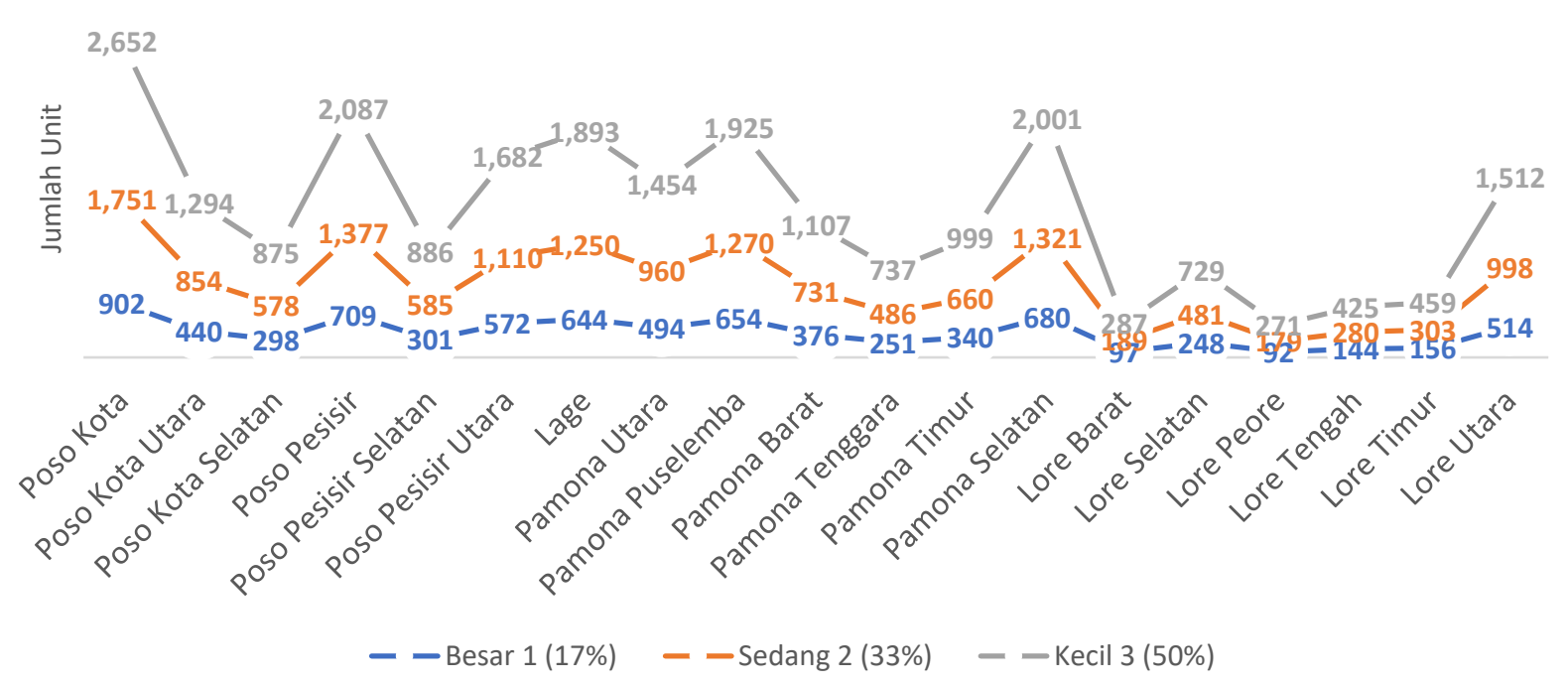

Gambar 2. Grafik tingkat kebutuhan rumah dengan tipe mewah, sederhana dan kecil pada tahun 2039 di Kabupaten Poso

Dari grafik di atas dapat dilihat bahwa kecamatan yang paling tinggi tingkat kebutuhan rumah dengan tipe mewah, sederhana dan kecil pada tahun 2039 adalah Kecamatan Poso Kota. Hal tersebut karena Kecamatan Poso Kota memiliki paling banyak pertambahan penduduk dari tahun 2017 sampai dengan tahun 2039 yaitu dengan perkiraan jumlah penduduk sekitar 37.699 jiwa pada tahun 2039.

Kebutuhan lahan untuk pembangunan rumah baru dihitung berdasarkan luasan kapling dari tipe kecil, sedang dan besar. Untuk kapling tipe kecil luas lahan yang diarahkan maksimal $72 \mathrm{~m}^{2}$, luas kapling tipe sedang dengan luas maksimal $150 \mathrm{~m}^{2}$ dan untuk tipe besar maksimal $200 \mathrm{~m}^{2}$.
Kebutuhan lahan untuk perumahan tahun 2039 sebesar 739,78 Ha. Kebutuhan lahan tersebut untuk perumahan dan kawasan permukiman diarahkan ke kawasan-kawasan yang masih memiliki lahan yang luas dan memenuhi kriteria untuk suatu hunian yang layak, yang peruntukannya untuk perumahan dan kawasan permukiman harus mengacu kepada RTRW Kabupaten Poso. Untuk sepuluh tahun kedepan perlu diarahkan untuk lokasi Kasiba/Lisiba yang sudah ada embrio pengembangannya. 
Ketersediaan Lahan, Daya Dukung dan

Daya Tampung Perumahan dan Kawasan

\section{Permukiman}

Lahan yang merupakan faktor utama sebagai dasar dalam pembangunan perumahan dan kawasan permukiman seringkali menjadi masalah karena keterbatasan luasan yang tersedia terutama di kawasan pusat kota, Lahan yang digunakan untuk kawasan perumahan dan kawasan permukiman ini harus memenuhi persyaratan yang layak huni untuk dapat berlanjut (sustainable).

Alternatif lahan yang dapat digunakan untuk perumahan dan kawasan permukiman diperoleh dengan melakukan serangkaian analisis dimulai dari Tahapan analisis proyeksi pertumbuhan penduduk time series, Tahap analisis kemampuan lahan, Tahap analisis nilai potensi pertumbuhan permukiman dan Tahap analisis perkembangan permukiman. Berdasarkan hasil analisis beberapa data sesuai dengan persyaratan seperti tersebut diatas, sehingga lahan yang dapat digunakan adalah lahan non produktif, lahan yang kemiringannya di bawah 25\%, memiliki kecenderungan kompak, sesuai dengan rencana tata ruang wilayah Kabupaten Poso, tidak rawan bencana (tsunami, gempa bumi, banjir, longsor dan abrasi), bukan daerah negatife list.

Untuk daerah perkotaan yang sudah sangat padat sehingga lahan yang tersedia untuk pembangunan perumahan baru dalam skala besar tidak dimungkinkan, sehingga pembangunan perumahan yang dilakukan di daerah perkotaan ada beberapa alternatif yang dimungkinkan antara lain:

- Pembangunan perumahan baru di kawasan pusat kota dengan kepadatan tinggi diarahkan untuk pembangunan secara vertikal seperti pembangunan rumah susun atau apartemen, yaitu di lokasi yang berpotensi memiliki kepadatan bangunan tinggi Kecamatan Poso Kota, Poso Kota Utara, dan Lore Barat.

- Memanfaatkan lahan permukiman di lokasi yang masih memiliki kepadatan tidak terlalu tinggi, yaitu dengan cara mengoptimalkan lahan pekarangan yang masih dimungkinkan untuk dikembangkan.

- Mengarahkan lahan kebutuhan perumahan untuk penduduk di kawasan perkotaan ke daerah pinggiran kota.

Untuk daerah pinggiran atau daerah yang masih bercirikan perdesaan tidak semuanya dapat dibangun untuk perumahan 
dan kawasan permukiman. Alternatif pengembangannya adalah:

- Di daerah yang kelerengannya di bawah $25 \%$.

- Bukan merupakan daerah konservasi/kawasan lindung.

- Lokasi mudah dicapai, memiliki kecenderungan kompak, dan sesuai dengan arah pengembangan dari rencana tata ruang kabupaten

- tidak rawan bencana (tsunami, gempa bumi, banjir, longsor dan abrasi),

- bukan daerah negative list.

Daya dukung perumahan dan kawasan permukiman merupakan potensi yang dapat dijadikan sebagai pertimbangan lokasi untuk pembangunan perumahan dan kawasan permukiman baru. sebagai factor limitasi pembangunan, diketahui bahwa Kabupaten Poso memiliki kawasan bahaya bencana dengan kategori tinggi yang sangat besar yakni seluas 338.963,56 Ha atau kurang lebih sekitar 36\% dari Wilayah Kabupaten Poso. Zona rawan bahaya kategori tinggi di Kabupaten Poso didominasi oleh bahaya Gerakan tanah yakni sekitar 272.637,42 Ha, selanjutnya bahaya banjir yakni sekitar 41.836,62 Ha, bahaya gempa bumi yakni sekitar 20.505,26 Ha, dan yang terakhir bahaya tsunami yakni sekitar 3984,27 Ha.
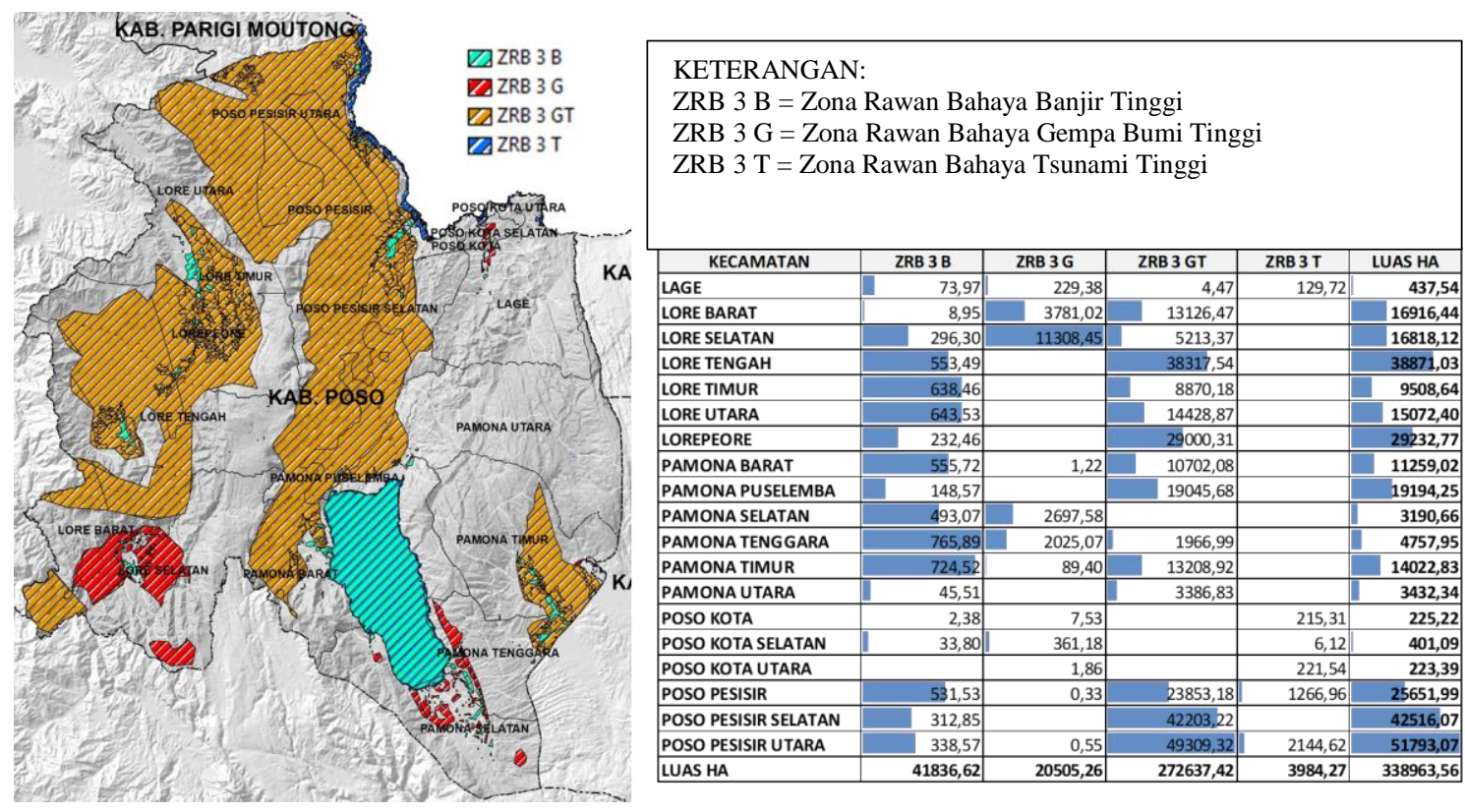

Gambar 3. Kawasan Bahaya Bencana Tinggi di Kabupaten Poso 
Alokasi Ruang Perumahan dan Kawasan

Permukiman berdasarkan rencana Tata

Ruang Wilayah Kabupaten serta

rekomendasi Hasil Penelitian

Berdasarkan hasil analisis jumlah rumah tahun 2017 di Kota Poso adalah 50.732 unit. Dengan jumlah Backlog sebanyak 8.851. Jumlah backlog tertinggi berada di Kecamatan Poso Kota sebanyak 925 unit, Kecamatan Pamona Selatan sebanyak 845 unit, Kecamatan Lage 844 Jiwa, dan Kecamatan Poso Pesisir 838 Unit. Dengan metode proyeksi secara linier dan koefisien hunian ideal 4jiwa/kk, diperkirakan jumlah rumah di Kabupaten Poso pada tahun 2039 mencapai 97.287 dan kebutuhan rumah tahun 2017-2039 mencapai 46.555 unit. Segmentasi kebutuhan rumah Besar sebanyak 7.914 unit, Sedang 15.363 unit, dan Kecil 23.277 unit dengan total luas
Perumahan untuk ketiga tipe tersebut sebanyak 556,33 Ha.

Berdasarkan kajian revisi RTRW Kabupaten Poso ('Revisi RTRW Kabupaten Poso Tahun 2012-2032', 2019), alokasi pola ruang untuk Perumahan dan Kawasan Permukiman mencapai 6158,52 atau sebesar $32,45 \%$ dari Luas guna lahan perumahan dan Kawasan permukiman eksisting di tahun 2017. Luasan Pola Ruang untuk perumahan dan kawasan permukiman dalam Revisi RTRW Kabupaten Poso tersebut masih belum mempertimbangkan Kawasan negative list antara lain $\mathrm{KP} 2 \mathrm{~B}$, Kawasan pengukuhan kehutanan sesuai SK 8113, Kawasan pertambangan dengan status IUP Produksi, Kajian Kawasan Rawan Bencana, serta arahan revisi RTRW Provinsi Sulawesi Tengah.

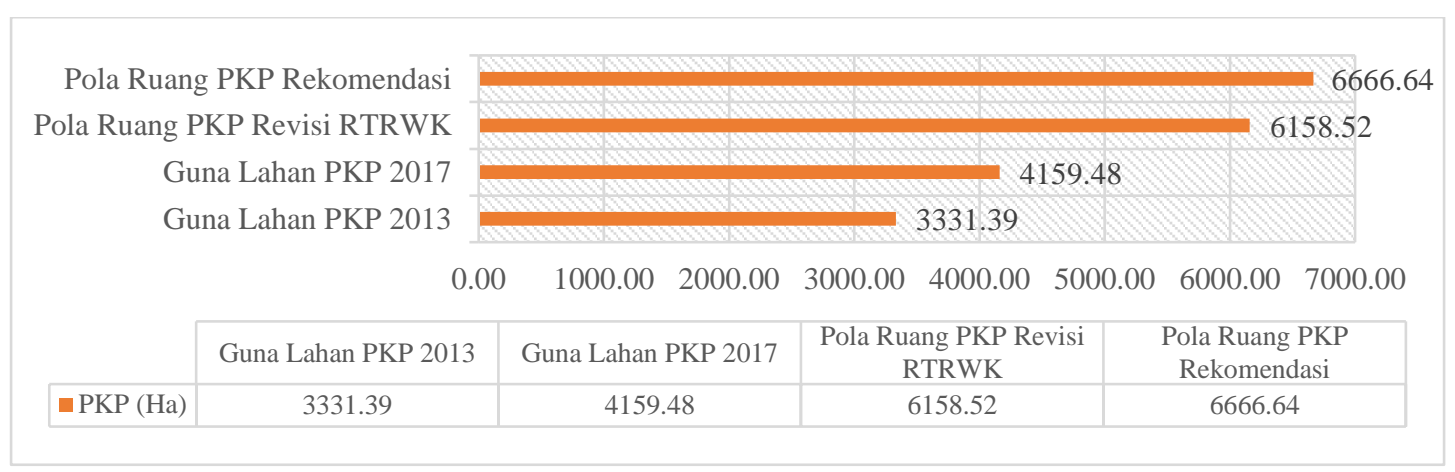

Gambar 4. Grafik Perbandingan Guna Lahan dan Rencana Alokasi Ruang untuk Pengembangan Perumahan dan Kawasan Permukiman Kabupaten Poso 
Tabel 2. Alokasi, Kebutuhan, dan Potensi Pengembangan Lahan untuk Perumahan dan Kawasan Permukiman Sampai Tahun 2039

\begin{tabular}{|c|c|c|c|}
\hline Kecamatan & $\begin{array}{c}\text { Alokasi Pola } \\
\text { Ruang PKP 2017- } \\
2039(\mathrm{Ha})\end{array}$ & $\begin{array}{l}\text { Kebutuhan Ruang } \\
\text { PKP Tahun } 2039 \\
\text { PKP (Ha) }\end{array}$ & $\begin{array}{c}\text { Potensi Arahan } \\
\text { Pengembangan PKP } \\
\text { Tahun } 2039(\mathrm{Ha})\end{array}$ \\
\hline Poso Kota & 294,2 & 187,71 & 106,49 \\
\hline Poso Kota Utara & 194,99 & 102,43 & 92,56 \\
\hline Poso Kota Selatan & 244,33 & 83,29 & 161,04 \\
\hline Poso Pesisir & 504,4 & 186,29 & 318,11 \\
\hline Poso Pesisir Selatan & 388,63 & 81,89 & 306,74 \\
\hline Poso Pesisir Utara & 421,73 & 145,31 & 276,42 \\
\hline Lage & 370,44 & 168,41 & 202,03 \\
\hline Pamona Utara & 685,93 & 113,13 & 572,80 \\
\hline Pamona Puselemba & 403,69 & 166,55 & 237,14 \\
\hline Pamona Barat & 311,49 & 86,45 & 225,04 \\
\hline Pamona Tenggara & 178,75 & 59,97 & 118,78 \\
\hline Pamona Timur & 589,72 & 88,20 & 501,52 \\
\hline Pamona Selatan & 1194,08 & 170,22 & 1023,86 \\
\hline Lore Barat & 35,38 & 25,99 & 9,39 \\
\hline Lore Selatan & 188,21 & 52,05 & 136,16 \\
\hline Lore Peore & 102,99 & 27,18 & 75,81 \\
\hline Lore Tengah & 101,62 & 37,26 & 64,36 \\
\hline Lore Timur & 206,32 & 45,09 & 161,23 \\
\hline Lore Utara & 249,74 & 110,22 & 139,52 \\
\hline Total & $6.666,64$ & $1.937,63$ & $4.729,01$ \\
\hline
\end{tabular}

Berdasarkan hasil analisis, luasan Pola Ruang ideal yang direkomendasikan untuk pembangunan dan pengembangan perumahan dan kawasan permukiman adalah sebesar 6.666,64 Ha. Besaran alokasi ruang ini lebih besar 508,12 Ha dari alokasi ruang dalam revisi RTRW Kabupaten Poso.

Kebutuhan Ruang tiap Kecamatan untuk Pengembangan Perumahan dan Kawasan Permukiman Kabupaten Poso sampai Tahun 2039 masih sangat mencukupi. Kebutuhan terbesar diprediksi berada di kecamatan Poso Kota yakni sekitar 187,71 Ha, kemudian Kecamatan Poso Pesisir yakni sekitar 186,29 Ha, Kecamatan Pamona
Selatan yakni sebesar 170,22 Ha, Kecamatan Lage yakni 168,41 Ha, dan Kecamatan Pamona Pusalemba yakni sebesar 166,55 Ha. Berdasarkan perbandingan antara "Potensi ketersediaan lahan" dengan "Kebutuhan lahan" ditahun 2039 dapat terlihat bahwa Ketersediaan Lahan untuk pembangunan dan pengembangan perumahan dan Kawasan permukiman di Kabupaten Poso masih sangat mencukupi terlebih pada kecamatan pamona selatan.

Arahan pengembangan lahan untuk perumahan dan kawasan permukiman berada pada beberapa Kawasan aglomerasi penduduk, antara lain Kawasan Perkotaan 
Poso, Kawasan Perkotaan Tentena, Kawasan Permukiman Pesisir bagian Utara, Kawasan Transmigrasi Tampolore, dan Kawasan Transmigrasi Pamona. Potensi ketersediaan lahan terbesar berdasarkan kecamatannya untuk pembangunan dan pengembangan perumahan dan Kawasan permukiman di Kabupaten Poso berada di Kecamatan Pamona Selatan yaitu sebesar 1.194,08 Ha, sedangkan potensi ketersediaan lahan terkecil berada dikecamatan Lore Barat dengan luasan 35,38 Ha.

Potensi cadangan lahan untuk arahan pengembangan Perumahan dan Kawasan Permukiman Kabupaten Poso paling besar berada di Kecamatan Pamona Selatan yakni sebesar 1023,86 Ha, kemudian Kecamatan Pamona Utara yakni sebesar 572,80 Ha, dan kecamatan Pamona Tumur yakni sebesar 501,52 Ha. Potensi cadangan lahan untuk arahan pengembangan Perumahan dan Kawasan Permukiman Kabupaten Poso paling sedikit berada di Kecamatan Lore Barat yakni sebesar 9,39 Ha, Kecamatan Lore Tengah yakni sebesar 64,36 Ha, Kecamatan Lore Peore yakni sebesar 75,81 Ha, Kecamatan Poso Kota Utara yakni sebesar 92,56 Ha, dan Kecamatan Poso Kota yakni 106,49 Ha.

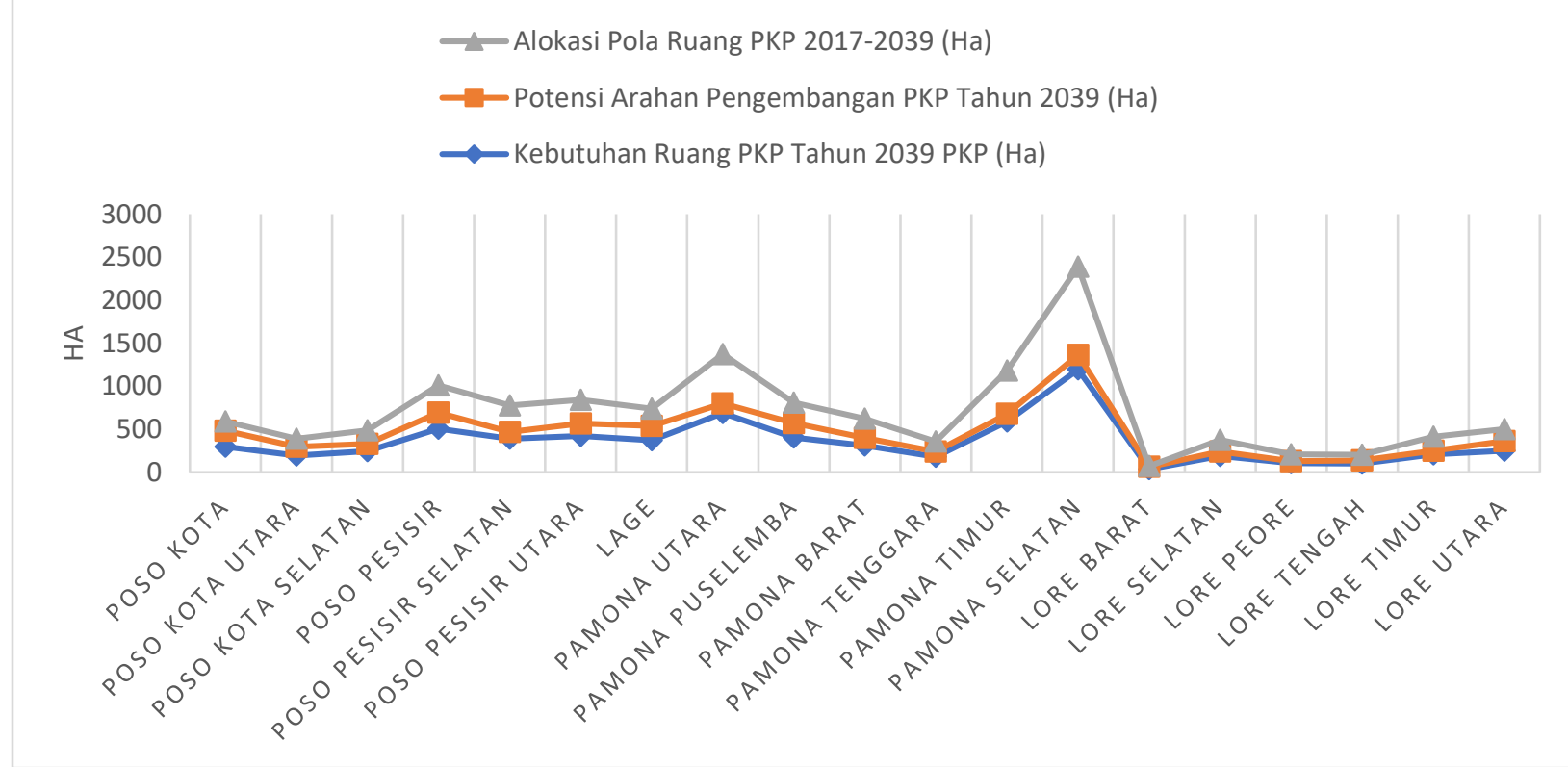

Gambar 5. Grafik Perbandingan Alokasi Pola Ruang, Potensi Arahan, serta Kebutuhan Ruang tiap Kecamatan untuk Pengembangan Perumahan dan Kawasan Permukiman Kabupaten Poso 


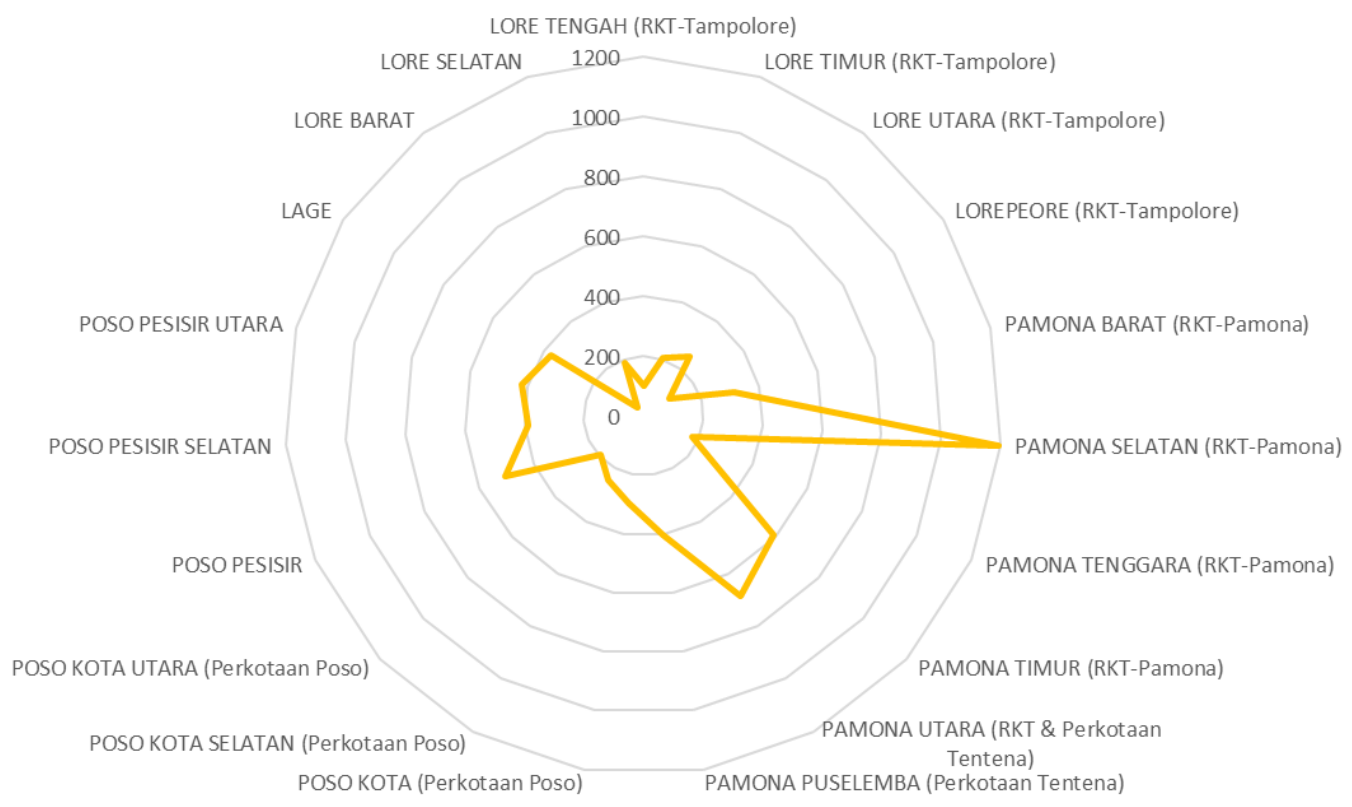

Gambar 6. Potensi Pengembangan Lahan untuk Perumahan dan Kawasan Permukiman Sampai Tahun 2039

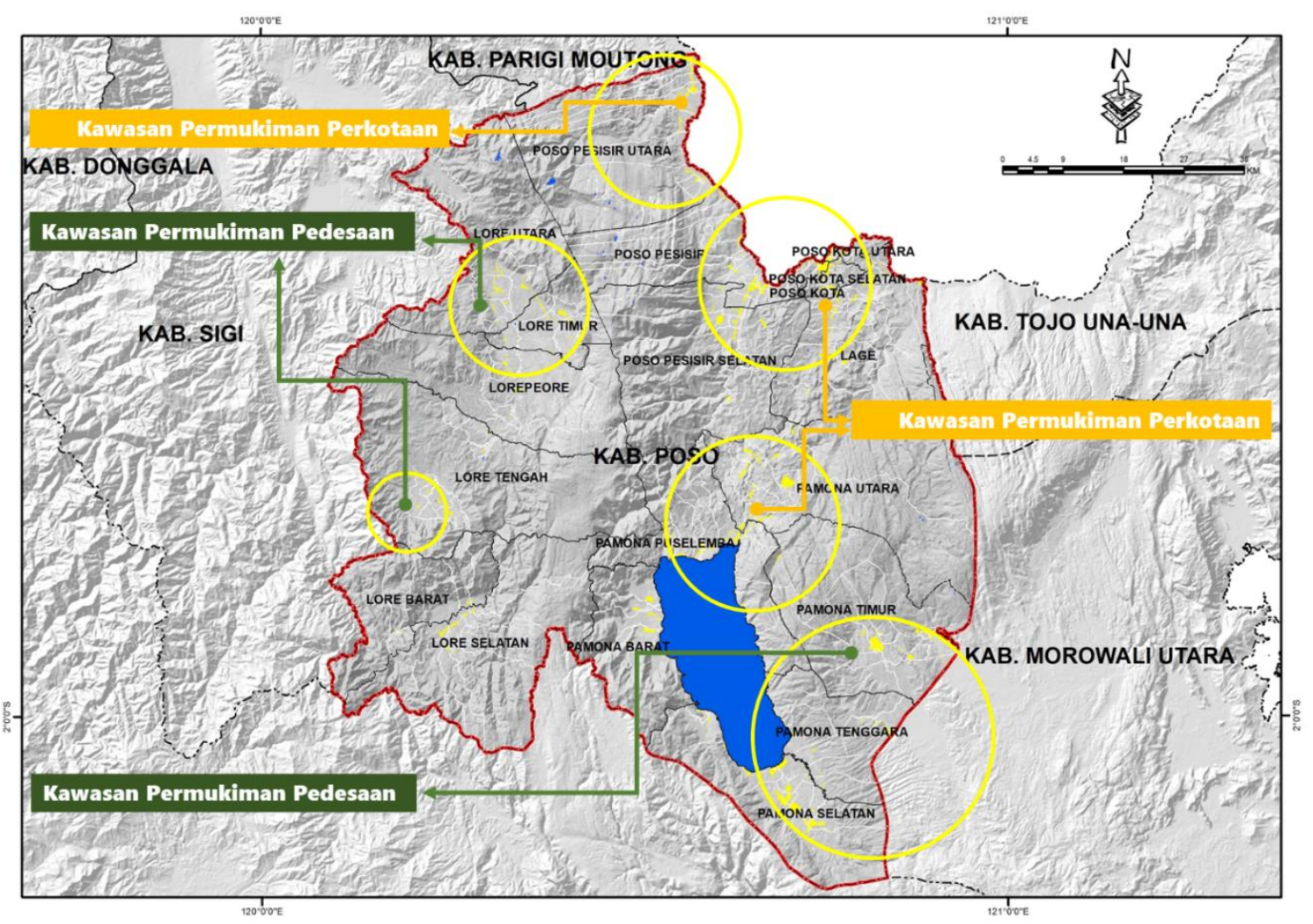

Gambar 7. Arahan Pengembangan Lahan untuk Perumahan dan Kawasan Permukiman 
Potensi Pengembangan Lahan untuk Perumahan dan Kawasan Permukiman Sampai Tahun 2039 di Kabupaten Poso masih sangat besar yakni 6.666,64 Ha. Jika dibandingkan dengan kebutuhan ruang yang harus diperuntukkan untuk Perumahan dan Kawasan Permukiman Sampai Tahun 2039 yang sebesar 1.937,63 Ha, berarti Kabupaten Poso masih memiliki Cadangan Lahan untuk Perumahan dan Kawasan Permukiman sebesar 4.729,37.

Pembangunan Perumahan dan kawasan permukiman dilaksanakan melalui upaya penataan pola dan struktur ruang pembangunan rumah beserta prasarana, sarana, dan utilitas umum yang terpadu dengan penataan lingkungan sekitar.

\section{PENUTUP}

Berdasarkan hasil analisis yang telah dilakukan, ditemukan bahwa luasan Pola Ruang untuk perumahan dan kawasan permukiman dalam Revisi RTRW Kabupaten Poso tersebut masih belum mempertimbangkan Kawasan negative list antara lain KP2B, Kawasan pengukuhan kehutanan sesuai SK 8113, Kawasan pertambangan dengan status IUP Produksi, Kajian Kawasan Rawan Bencana, serta arahan revisi RTRW Provinsi Sulawesi Tengah. Luasan Pola Ruang ideal yang direkomendasikan untuk pembangunan dan pengembangan perumahan dan kawasan permukiman adalah sebesar 6.666,64 Ha. Besaran alokasi ruang ini lebih besar 508,12 Ha dari alokasi ruang dalam revisi RTRW Kabupaten Poso. Perbandingan Alokasi Pola Ruang, Potensi Arahan, serta Kebutuhan Ruang tiap Kecamatan untuk Pengembangan Perumahan dan Kawasan Permukiman Kabupaten Poso. Kebutuhan Ruang tiap Kecamatan untuk Pengembangan Perumahan dan Kawasan Permukiman Kabupaten Poso sampai Tahun 2039 masih sangat mencukupi terlebih pada kecamatan pamona selatan.

Arahan pengembangan lahan untuk perumahan dan kawasan permukiman berada pada beberapa Kawasan aglomerasi penduduk, antara lain Kawasan Perkotaan Poso, Kawasan Perkotaan Tentena, Kawasan Permukiman Pesisir bagian Utara, Kawasan Transmigrasi Tampolore, dan Kawasan Transmigrasi Pamona. 


\section{DAFTAR PUSTAKA}

Dewi, A. P. and Sunaryo, B. (2013)

'Analisis Kesesuaian Lahan Kawasan

Permukiman Bagi Masyarakat Golongan

Menengah keatas di Kecamatan Ngaliyan,

Semarang', Teknik PWK (Perencanaan

Wilayah Kota), 2(3), pp. 434-443.

Kusuma, S. H. (2017) 'Arahan

Pengembangan Perumahan dan Kawasan

Permukiman di Kabupaten Probolinggo, berdasarkan Kesesuaian Lahan', Jurnal

Penataan Ruang, 12(1), pp. 41-47. doi:

10.12962/j2716179X.v12i1.5223.

PP No. 12 Tahun 2021 tentang Perubahan

atas Peraturan Pemerintah Nomor 14

Tahun 2016 tentang Penyelenggaraan

Perumahan dan Kawasan Permukiman

(2021). Available at:

https://peraturan.bpk.go.id/Home/Details/16

1842/pp-no-12-tahun-2021 (Accessed: 4

March 2021).

'Revisi RTRW Kabupaten Poso Tahun

2012-2032' (2019). Dinas Pekerjaan Umum dan Penataan Ruang Kabupaten Poso.

UU No. 1 Tahun 2011 tentang Perumahan

dan Kawasan Permukiman (2011).

Available at:

https://peraturan.bpk.go.id/Home/Details/39

128/uu-no-1-tahun-2011 (Accessed: 4

March 2021).

'Wikipedia Poso (kota)' (2021) Wikipedia

bahasa Indonesia, ensiklopedia bebas.

Available at:

https://id.wikipedia.org/w/index.php?title=P

oso_(kota)\&oldid=17895867 (Accessed: 4

March 2021). 